\title{
PSA Level Less than 0.1
}

National Cancer Institute

\section{Source}

National Cancer Institute. PSA Level Less than 0.1. NCI Thesaurus. Code C138071.

An indication that a blood concentration of prostate specific antigen below $0.1 \mathrm{ng} / \mathrm{mL}$ was detected in a sample. 